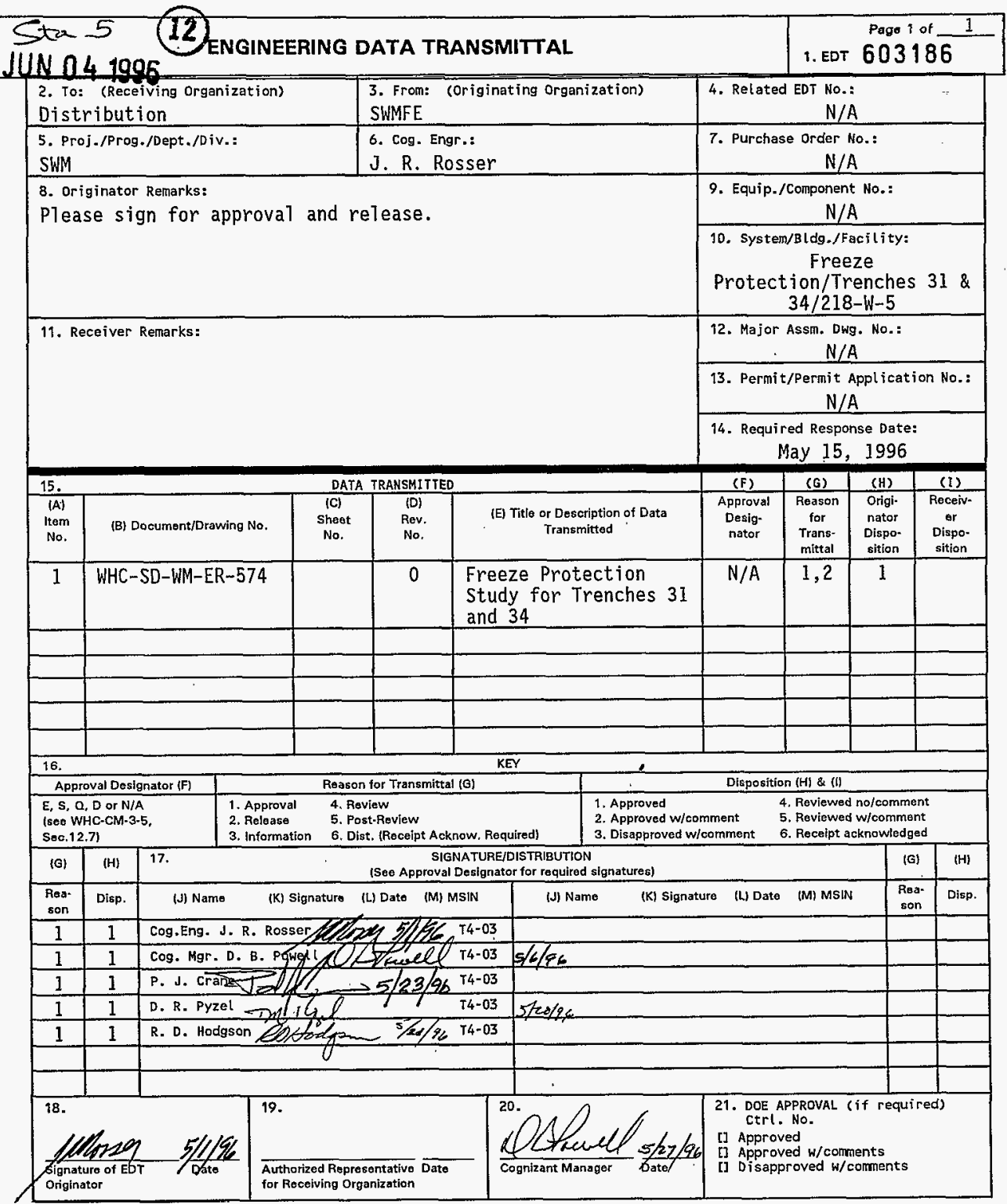




\section{Freeze Protection Study for Trenches 31 and 34}

J.R. Rosser

Westinghouse Handford Co., Richland, WA 99352

U.S. Department of Energy Contract DE-AC06-87RL10930
EDT/ECN: 603186
Org Code: 87250
UC: $U C-512$
B\&R Code: EW3130020
Charge Code: A6V10
Total Pages: 9

Key Words: Heat, Freezing, Piping, Trench

Abstract: This document is an engineering study and analysis to determine the most efficient and cost effective means to prevent water freezing in the Trench 31 and 34 leachate collection systems.

TRADEMARK DISCLAIMER. Reference herein to any specific commercial product, process, or service by trade name, trademark, manufacturer, or otherwise, does not necessarily constitute or imply its endorsement, recommendation, or favoring by the United states Government or any agency thereof or its contractors or subcontractors.

Printed in the United States of America. To obtain copies of this document, contact: WHC/BCS Document Control Services, P.0. Box 1970, Mailstop H6-08, Richland HA 99352, Phone (509) 372-2420; Fax (509) 376-4989.
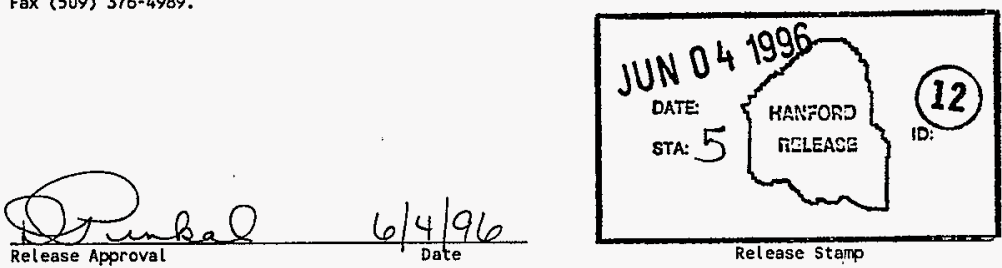

\section{Approved for Public Release}


WHC-SD-WM-ER-574, Rev.0

FREEZE PROTECTION STUDY

FOR

TRENCHES 31 AND 34

Apri1, 1996 
WHC-SD-WM-ER-574, Rev.0

CONTENTS

1.0 OBJECTIVE

1.1 BACKGROUND AND SCOPE ................. 1

1.2 PURPOSE AND NEED $\ldots \ldots \ldots \ldots$

2.0 SUMMARY . . . . . . . . . . . . . . . 1

3.0 RECOMMENDATIONS AND CONCLUSIONS .............. 2

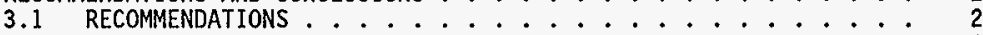

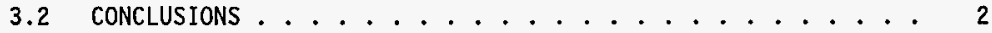

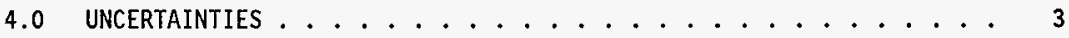

5.0 DESCRIPTION OF ALTERNATIVES AND SOLUTIONS .......... 3

5.1 CRITERIA ...................... 3

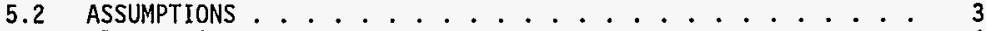

5.3 Alternatives ................. 4

5.3.1 A7ternative One (4); 5.3.2 Aiternative Two (4)

6.0 DISCUSSION OF PREFERRED ALTERNATIVE/SOLUTION . . . . . . . 5

7.0 NO ACTION ALTERNATIVE ................... 5

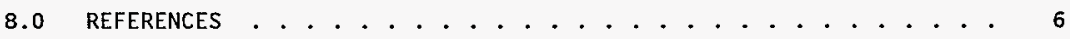


WHC-SD-WM-ER-574, Rev.0

\subsection{OBJECTIVE}

\subsection{BACKGROUND AND SCOPE}

A heat trace thermostat failure in the winter of 1994-95 prevented heat trace from activating thus allowing some freezing to occur in the Trench $31 / 34$ leachate collection piping and tanks. This was fixed by bypassing the thermostats at both trenches and turning on the heat trace during the winter months. There was indication of freezing in Trench 34 sample port \# I line this winter (1995-96) and a plug-in heat wire was wrapped around it, along with insulation placed around Trench 34 sample port \#2 piping. After talking with the Operators and Craft personnel, it has been determined that there has been no physical indication, such as flow blockage, of water freezing in the main leachate collection piping or tank at either trench this winter. Each trench has had bi-metal dial thermometers with stems inserted through the insulation at various places along the piping and tank. During this winter, severat of these thermometers indicated below freezing readings; therefore, on February 2 , 1996, electrically heated concrete curing blankets and wrap insulation were placed around a large portion of the piping.

\subsection{PURPOSE AND NEED}

Operations is unsure if the installed heat trace is sufficient to keep the leachate collection piping and tank from freezing. Operations has also indicated a need for some type of backup for the heat trace in case of electrical power failure. Freezing could cause breakage and leakage in the system. Once the trenches become operational, the State of Washington Dangerous Waste Regulations, Chapter 173-303 WAC, require a functioning leachate collection and removal system. A breakage in this system caused by freezing would not only prevent it from operating, it would also be difficult to repair because of the possibility of the leachate being designated a mixed waste.

\subsection{SUMMARY}

The purpose of this study is to evaluate the adequacy of existing freeze protection installed on the Teachate collection piping and tank for Trenches 31 and 34 and make recommendations to ensure that these systems are sufficiently heated to prevent water collected in them from freezing. Alternatives evaluated as a means to upgrade the freeze protection system included; (1) do nothing, (2) completely replace the existing system with new heat trace and add insulation, (3) replace the temperature indication and/or, (4) provide a temporary backup to the existing heat trace system with portable heaters. The preferred alternative is to keep the current heat trace system with minor additions to 
WHC-SD-HM-ER-574, Rev.0

insulation, update the current temperature and thermostat monitoring, and use portable heaters in conjunction with the piping and tank enclosures currentiy being built. The data indicated that the existing heat trace has been working and that a11 reported problems occurred either due to thermostat faiture or no insulation. Estimated total cost would be $\$ 5430$ ( $\$ 6930$ if portable heaters are purchased).

\subsection{RECOMMENDATIONS AND CONCLUSIONS}

\subsection{RECOMMENDATIONS}

- Place thermocouple temperature probes, along with remote switch and readout, to replace existing thermometers. This witl establish if current heat trace system is keeping the pipes and tank above freezing. - Replace or refit existing thermostats to have indicating light showing that heat trace has been activated. This will ensure the heat trace has been activated with minimal surveillance.

- Ensure that all piping is insulated (this would be a minimal addition to sample port piping).

- Also place Trench 34 sample port \#1 valve closer to the main line. This would prevent leachate remaining in small uninsulated areas where it is most likely to freeze.

- Take advantage of the tank and piping enclosure currently being built. The enclosure will block wind and its accompanying heat loss. Although it is not an insulated structure it will provide a boundary where a portable electric forced air heater can be placed to provide a backup heat source to supplement the existing heat trace (if it is found to be needed). In addition, in the unlikely event of total power failure the portable heaters could be used with power from a portable generator.

\subsection{CONCLUSIONS}

With only minor modifications, the existing freeze protection system in Trenches 31 and 34 should be adequate to prevent water freezing in the pipes and tanks. The only known freezing occurred when the thermostat failed and in one sample port at Trench 34 . This sample port has about 6 to 8 inches of uninsulated pipe extending from the main pipe line then a valve, thus allowing this section of uninsulated pipe to retain water. The same sample port at Trench 31 has the valve located as close to the main pipe as possible, thus not having a length of uninsulated pipe retaining water and apparently had no freezing problems. The data from the thermometers is suspect at best. They were not placed in thermowells, allowing only a small fraction of the sensing element to contact the pipe. Their placement in relation to the heat trace wire was unknown. In lines where the thermometer was showing below freezing (i.e., 28 degrees F), the flow of water was not blocked. On days that 
showed little change in the outside ambient temperature from the previous day, the thermometers at certain locations would show large differences (i.e., an increase of over 25 degrees F) from the previous days reading. There were a1so large differences between thermometers along the same piping section (i.e., one thermometer would show 17 degrees and just a few feet down the line the next would show 30 degrees). The effect of the added concrete curing blankets on the thermometers is also unknown. The existing heat trace was placed and tested in accordance with Construction Quality Assurance Reports WHC-SDW025-RPT-001 and WHC-SD-W025-RPT-002. A17 indications (except for the suspect thermometer data) show that when the heat trace was powered there was no freezing in the insulated piping and tanks.

\subsection{UNCERTAINTIES}

- Uncertainties include accuracy of the present thermometer temperature readings. Since the thermometers were placed without thermowells, their data is highly suspect.

- Did the addition of electricaliy heated curing blankets hide the fact that certain areas of heat trace were not sufficient? There had been sufficient cold temperatures, without indication of freezing prior to blankets being placed, to assume that the blankets did not mask a problem.

\subsection{DESCRIPTION OF ALTERNATIVES AND SOLUTIONS}

\subsection{CRITERIA}

(1) Water stored in the leachate piping and tank will not freeze during cold weather operations.

(2) There is indication that the heat trace has been activated or powered.

(3) There is reliable indication that water in the piping and tanks is above freezing temperatures.

(4) In case of total electrical power failure to the trenches, the water stored in the leachate piping and tank can be kept from freezing by an alternate power source, until electrical power is restored.

\subsection{ASSUMPTIONS}

(1) The heat trace was placed and tested properly as stated in the Construction Quality Assurance Report and the Certified Vendor Information.

(2) All available data and information has been received from Operations and Maintenance and is valid. 
WHC-SD-WM-ER-574, Rev. 0

\subsection{ALTERNATIVES}

\subsubsection{Alternative One}

(a) Take off all the piping insulation, see where the existing heat trace wire is located, add more wire as needed, and replace insulation. Estimated labor cost of 2 insulators for 20 days and 1 electrician for 2 days is $\$ 11,760$. Estimated material cost is $\$ 1,000$ for heat trace wire and possible replacement of damaged insulation. Take off all tank insulation, see where the existing heat trace wire is located, add more wire as needed, and replace insulation. Estimated cost of labor and material is the same as the piping, which is $\$ 11,760$. Doing this insulation removal and replacement will be very difficuit with the piping and tank enclosures currently in place. It is impossible to determine how much original insulation could be reused. The price will jump significantly if most or all of the existing insulation can't be used again.

(b) Place thermocouple temperature probes, along with remote switch and readout to replace existing thermometers. Estimated labor cost of 2 electricians for 4 days and 1 insulator for 2 days is $\$ 2,800$. Estimated material cost is $\$ 2,000$.

(c) Replace or refit existing thermostats to have indicating light showing that heat trace has been activated. Estimated labor cost of 1 electrician 1 day is $\$ 280$ and estimated material cost of $\$ 150$.

\subsubsection{Alternative Two}

(a) Do steps (b) and (c) in Alternative One.

(b) Ensure that all piping is insulated (this would be a minimal addition to sample port piping). Also place Trench 34 sample port \#1 valve closer to the main line like Trench 31 sample port \#1 valve. Labor and material cost would be minimal, $\$ 100$ to $\$ 200$.

(c) Take advantage of the tank and piping enclosure currently being built. The enclosure will block wind and its accompanying heat loss. Although it is not an insulated structure it will provide a boundary where a portable electric forced air heater can be placed to provide a backup heat source to supplement the existing heat trace (if it is found to be needed). In addition, in the unlikely event of total power fajlure, the portable heaters could be used with power from a portable generator. Estimated cost would be zero if existing heaters are used or $\$ 750$ per heater if new ones are bought. There is currently a possible concern with a Fire Hazardous Analysis (FHA). According to James Keene the tank enclosure was not addressed in the FHA. An FHA has not yet been provided concerning the use of portable electric heaters in the enclosure, but the FHA should not be a problem. 
WHC-SD-HM-ER-574, Rev. 0

\subsection{DISCUSSION OF PREFERRED ALTERNATIVE/SOLUTION}

The current historical information is insufficient to warrant going to the trouble and expense of taking off and replacing all the pipe and tank insulation in Alternative One. Talks with maintenance craft indicated that this would be a very messy job with many uncertainties concerning damaging the existing insulation and heat trace. These uncertainties could affect any cost estimate. The cost of Alternative One is $\$ 28,750$ which is almost $\$ 22,000$ more than Alternative Two. Because of these and other reasons, Alternative Two appears to be a better choice. Alternative Two will implement all of Alternative one, except for the removal and re-installation of insulation and the possible installation of additional of heat trace wire. The addition of thermocouple temperature readout should give a better indication of how well the current heat trace is working. In case it is found that certain sections of the heat trace is insufficient, just that section could be heat trace supplemented, not the entire piping and tank system. There is sufficient backup heat source, with existing electric curing blankets, to keep any section of pipe or tank from freezing until permanent additional heat trace is added. The addition of a light indicator that shows the thermostat is working, along with a central temperature readout, will give Operations timely indication of the operability of the heat trace. The use of forced air electric heaters will also provide an emergency backup with portable generators, if power is lost.

\subsection{NO ACTION ALTERNATIVE}

If no action is taken, operations will continue like this past winter. There will be uncertainty on the operational efficiency of the heat trace. The addition of the piping and tank enclosure will block the wind, thus providing some freeze protection. The wrap insulation and electric curing blankets could be used again to supplement heat trace and the electric heat tape would be used at the uninsulated sample port. Currently, there is no funding to accept waste in Trenches 31 and 34 prior to next winter (1996-1997). If this is true, there will be little immediate impact on programs if no action is taken. But if a decision is made to use the trenches as a storage area, for such waste as the Long Length Contaminated Equipment, the possibility exists that they could be put into use by this next winter. If this became the case, it would be wise to at least have in place, equipment to help determine that the heat trace is working. 
WHC-SD-HM-ER-574, Rev.0

\subsection{REFERENCES}

Bylin, BTX Self-Regulating Heating Cable (Certified Vendor Information).

Golder, 1994, Construction Quality Assurance Report Radioactive Mixed Waste Land Disposal Facility Non-Draq-Off Project No. W-025 Hanford Site Richland. Washington, WHC-SD-W025-RPT-001, Rev.0.

Golder, 1995, Construction Quality Assurance Report Radioactive Mixed Waste Land Disposal Facility Non-Drag-Off-2 Project No. W-025 Second Landfill Hanford Site Richland. Washington, WHC-SD-W025-RPT-002, Rev.0.

Solid Waste Management, Trench $31 / 34$ Interim Operation surveillance data.

Washington State Department of Ecology, 1995, Dangerous Waste Regulations, Chapter 173-303 WAC. 